\title{
THE INSECTS OF SUGAR CANE IN SANTO DOIMINGO.
}

\author{
By George N. Wolcotw, Entomologist.
}

The only published record of the insects of sugar-cane in Santo Domingo is a "Report of the Entomologist's Inspection Trip to Santo Domingo" by W. V. Tower $\left({ }^{1}\right)$. In the files of the Insular Experiment Station, Río Piedras, Porto Rico are: (1) a supplementary report giving the determinations by specialists of the U. S. National Museum of the insects he collected, (2) a copy of the letter from C. B. Goueaux and H. Bourne to Mr. Van Alan Harris, administrator, Central Romana, La Romana, R. D., detailing their investigations at Higüeral on the Santo Domingo cane butterfly, incorrectly given as Calisto archebates Men., supplemented by (3) a determination sheet of the insects they collected, and (4), an extract from the diary of E. G. Smyth for the period when he was at Higüeral, collecting cane insects and working on the cane butterfly.

The author for five months was Entomologist at Estación Agronómica, Haina, R. D., but had little opportunity to observe the insects of sugar cane, except in the immediate vicinity of Haina. Nevertheless, additional observations were made at San Pedro de Macorís when returning to Porto Rico, which combined with the unpublished data, made possible the compiling of a list of insects of sugar cane in Santo Domingo, modeled on those of D. L. Van Dine in Porto Rico $\left({ }^{2}\right)$, G. E. Bodkin in Demerara $\left({ }^{3}\right)$ and T. E. Holloway and U. C. Loftin in the United States $\left(^{4}\right)$. The insects marked with a star are also found in Porto Rico and many of the less important are more fully treated in recent publications by E. G. Smyth $\left({ }^{5}\right)$ and by the author $\left({ }^{6}\right)$. Thanks are due to the various specialists for determinations. When no authority is given, the determination is by the author.

\section{A List of the Insects of Sugar Cane in Santo Domingo.}

\section{THYSANURA.}

No. 1*.-A green springtail, common on the underside of leaves.

No. 2*.-A grey springtail, common under dead leafsheaths on the stalk.

Determinations not yet received from Prof. J. A. Folsom. 


\section{ORTHOPTERA.}

No. 3*.-Schistocera pallens Thunbg. A large brown grasshopper, not common.

No. 4*.-Neoconocephalus triops macropterus Redt. and fuscostriatus Redt. A large all green or all grey or all brown grasshopper.

Determined by A. N. Caudell. Eggs are deposited under the green leafsheaths. Both nymphs and adults feed on leaves and are found hiding in the central whorl.

No. 5*.-Conocephalus cinereus Thunbg. Determined by A. N. Caudell. A small light-green grasshopper, with median dorsal brown stripe, not common on cane, more often feeds on coarse grass.

No. 6*.-Grillus assimitis Fabr. Determined by A. N. Caudell. A large cricket attacking young seedlings.

\section{HEMIPTERA-HETEROPTERA.}

No. 7*.-Lasiochilus divisus Champ. (P. R. specimens détermined by E. H. Gibson). A small brown Acanthiid bug, nymphs pinkish brown, common under leafsheaths, probably predaceous.

No. 8*.-Blissus leucopterus Say. The Chinch bug. Nymphs occassionally found in "dead-hearts," or on young shoots otherwise injured. All stages common on corn and rice.

\section{HEMIPTERA-HOMOPTERA.}

No. 9*.-Kolla (Tettigonia) similis Walk. (Determined as Tettigonia sp. near anita Fowl. and near prolixa Fowl. by 0. Heideman for W. V. Tower) The West Indian SugarCane Leafhopper. A large bright-green leafhopper with inconspicuous black markings and black underwings. All stages common on young plant cane. Adults have been found with one or two red mites attached.

No. 10.-Catonia intricata Uhler. Determined by W. L. McAtee. A mottled brown Fulgorid, not abundant, immature stages not observed.

No. 11.-Lamenia inflata? Ball. Determined by O. Heideman for W. V. Tower.

No. 12*.-Saccharosydne (Delphax or Stenocranus) saccharivora Westw. The West Indian Cane Fly. A Niagara green, transparent winged Fulgorid. Common, heavily parasitized, especially in the egg stage.

No. 13*.-Sipha flava Forbes. The Yellow Aphis of Sugar Cane. Common on the underside of the older leaves of young shoots. The ladybird beetles, Cycloneda sanguinea Linn. 
and Hyperaspis apicalis Weise, determined by E. A. Schwarz, found by W. V. Tower on sugar cane, are probably predaceous on this aphid.

No. 14.-Pseudococcus boninsis Kuwana. Determined by H. Morrison. A grey mealybug, on stalks not covered by leafsheats.

No. 15*.-Pseudococcus sp. prob. calceolariae Mask. A pink mealybug, on stalks under leafsheaths. Attended by Solenopsis geminata Fabr. and Prenelopsis longicornis Latr., determined by Dr. W. L. Mann.

\section{LEPIDOPTERA.}

No. 16.-Pyralid with leaf-rolling larva, brown head, creamy opalescent body, not bred to adult. Common in young cane, tying together the leaves of the central whorl.

No. 17*.-Diatraea prob. saccharalis Fabr. The Moth Stalk-Borer of Sugar Cane. Common. Larvae not bred to adult.

No. 18\%.-Laphygmo frugiperda S. \& A. The light-green form of larva common in young cane. Not bred to adult.

No. 19.-Helophila subpunctata Harvey. Reported from Higueral by Goueaux \& Bourne and Smyth. Larvae killed by a fungus.

No. 20*-Prenes ares Felder. Determined by H. G. Dyar. Fairly common. The larvae are bluish-grey green, with broad black collar above on posterior half of first segment. The head is yellow with brown median and lateral markings, the true legs and first spiracle black. Pupates in a loose cocoon in cane leaves to a creamy to light yellow biunt-ended chrysalis, head hairy, dark brown and with brown crescents on eyes and brown spots and dots dorsally. Adults brown, with largest yellow spot on forewing an irregular paralellogram. The larvae also feed on rice. Parasitized by Apanteles disputabitis Ashm., determined by C. F. W. Muesebeck

No. 21\%.-Prenes nero Fabr. Determined by H. G. Dyar. More: common on cane than $P$. ares. Larva all yellowish green. Chrysalis semitransparent green, with four light yellow stripes dorsally and a horn on the head, suspended in silken girdle in cane leaf. Adult brown, with largest yellow spot on forewing triangular.

No. 22.-Catia misera Lucas. Determined by H. G. Dyar. The smallest and most common Hesperid larva feeding on cane leaves, also common on rice and other coarse-leaved grasses. Larvae are green with purplish-brown head, variably marked with silvery or greenish yellow. Chrysalis much smaller, but similar in appearance to that of 
Prenes nero. Adult usually all brown, or with a few small yellow or light spots on wings, body slender.

No. 23\%.-Perichares corydon Fabr. Determined by H. G. Dyar. The largest and rarest Herperid. Larva yellowish green, noticeably pubescent with many long fine white hairs. True legs and head black in earlier instars. Head all green or marked with black (giving a dirty appearance underneath the pubesence) in last instar. Chrysalis large, similar in appearance to that of Presnes nero but darker green, with proboscis tube extending beyond caudum and with only two bright yellow stripes on dorsum. Adult is brown, with chestnut eyes, forewings each with four yellow spots and light brown crescent, all marked with lavender underneath.

No. 24.-Calisto pulchella Lathy. Determined by H. G. Dyar. The Santo Domingo Cane Butterfly. Dr. Dyar writing (apparently to Dr. L. O. Howard, Chief of the U. S. Bureau of Entomology) of the larvae and adults collected by W. V. Tower, says:

"Calisto of two species, apparently zangis Fabr. and archebates Men., but in bad condition. I am interested in Mr. Tower's discovery of the larva of Calisto. This seems to be a new enemy of sugar cane and will naturally be one only in the West Indies as the Calisto butterflies are confined to that region. I hope Mr. Tower will pursue the subject and secure a lot of good specimens of the butterflies, so I can make sure of the names."

(Calisto zangis occurs in Porto Rico but the larva has not been found feeding on sugar cane).

A few adults bred from larvae collected on cane by the author at San Isidro, R. D. (a short distance east of Santo Domingo City) were determined by Dr. Dyar, who reports them as C. pulchella Lathy. An abundance of adults collected by E. G. Smyth at Higueral in 1914 has recently been sent to Dr. Dyar, who reports a few as Calisto hysius Godt. but the great majority as C. pulchella. Calisto pulchella is undoubtedly the correct name for the economic species.

Very common Satyrid butterflies, especially at Higueral in December and January and at San Pedro de Macoris. The grey-brown mottled larvae hide in the central whorl, usually of large cane, eating the edges of the leaves, sometimes leaving nothing but the midribs. They pupate under old loose leafsheaths hanging to the stalks. Pupae are mottled brown and are parasitized by Chalcis annulata Fabr., determined by J. C. Crawford. The large brown butterflies, reddish on the hind wings, feed on the 
juice of cane discarded after being chewed by peons, and at mud-puddles.

\section{DIPTERA.}

No. 25.-Hippelates flavipes Loew. Determined by J. M. Aldrich. "Mimis." Small black flies common on young cane, causing no apparent injury, the larvae of which possibly breed in cane trash. The flies are annoying to man and animals.

\section{GOLEOPTERA.}

All determinations by E. A. Schwarz.

No. 26.-Hololepta quadridentata Fabr. A flat shining black Histerid beetle, predaceous or scavenger in injured cane stalks. Recorded by Smyth as usually found in the hold of boats bringing cane from Higueral for grinding in Porto Rico.

No. 27.-Chaetocnema prob. minuta Melsh. (Determined as C. apricaria for W. V. Tower). Small black flea-beetles, common on leaves of young cane. Feeding holes not observed. The larvae may feed on cane roots.

No. 28.-Diaprepes quadrivittatus Olivier. The Santo Domingo Weevil Root Borer. A large black beetle with four yellow or pink stripes on elytra. Adults feed on leaves of Inga vera and other plants, grubs bore into cane roots.

No. 29*.-Diaprepes spengleri comma Boheman. A variety of the common Weevil Root Borer of Porto Rico.

No. 30.-Metamasius sericeus Olivier. The Weevil Stalk Borer of Sugar Cane in the West Indies. The most obvious difference between this species and $M$. hemipterus Linn. of Porto Rico is in the coloration of the posterior two-thirds of the elytra, that of $M$. sericeus being black and that of $M$. hemipterus streaked with reddish-brown, tho in general appearance and habits the two species are quite similar. Recorded by Tower, Smyth and Goueaux \& Bourne at Higueral.

No. 31.-Hunter No. 3974. Calandrid. "Nothing similar to it in the National Museum collection." E. A. Schwarz. Small larvae causing "dead hearts" in young plant cane, common near San Isidro. One adult bred, crippled and immature.

No. 32.-Xyleborus sp. Shot-hole Borer. Reported by Tower at Higueral.

\section{BIBLIOGRAPHY.}

1. Tower, W. V. Report of the Entomologist's Inspection Trip to Santo Domingo. 2nd. Rpt. Bd. Comm. Agr. P. R. (1912-13), pp. $25-28$. 
2. VAN Dine, D. L. Insects Injurious to Sugar Cane in Porto Rico, and their Natural Enemies. Journ. Bd. Agr. Br. Guiana, April 1913, Vol. VI, No. 4, pp. 199-203.

3. BoDkin, G. E. Insects Injurious to Sugar Cane in British Guiana, and their Natural Enemies. Journ. Bd. Agr. Br. Guiana, July, 1913, Vol. VII, No. 1, pp. 29-32.

4 Holloway, T. E., and Loftin, U. C. Insects Attacking Sugar Cane in the United States. Journ. Economic Entomology, Vol. 12, No. 6, 1919, pp. 448-450.

5. Sмттн, E. G. Insects and Mottling Disease. Also List of the Insect and Mite Pests of Sugar Cane in Porto Rico. Journ. Dept. Agr. P. R., Vol. III, No. 4, October, 1919, pp. 83-112 and 135-150.

6. Wiolcotr, G. N. The Minor Sugar Cane Insects of Porto Rico, Journ. Dept. Agr. P. R., Vol. V, No. 2, April, 1921. 